\title{
Description and release of Australian gravity field model testing data
}

\author{
W. E. Featherstone ${ }^{a, c *}$, N. J. Brown ${ }^{b, c}$, J. C. McCubbine ${ }^{b, c}$ and M. S. Filmer \\ ${ }^{a}$ Department of Spatial Sciences \& The Institute for Geoscience Research, Curtin University of Technology, GPO Box U1987, \\ Perth, WA 6845, Australia \\ ${ }^{b}$ Geodesy Section, Community Safety and Earth Monitoring Division, Geoscience Australia, GPO Box 378, Canberra, ACT 2601, \\ Australia \\ ${ }^{\mathrm{c}}$ Also affiliated with the Cooperative Research Centre for Spatial Information for this project (Level 5, 204 Lygon Street, Carlton, \\ Vic 3053, Australia) \\ * corresponding author: w.featherstone@curtin.edu.au \\ Received 25 August 2017; accepted 28 November 2017
}

\section{ABSTRACT}

Gravimetric geoid and/or quasigeoid models are routinely evaluated using co-located GPS-levelling and/or astrogeodetic vertical deflections, globally and regionally. This short note describes these ground-truth data for Australia as of August 2017, which are provided as Electronic Supplementary Material. We provide 7500 GPS-derived ellipsoidal heights, normal-orthometric heights from the 1971 adjustment of the Australian Height Datum, normal heights from a readjustment of levelling constrained to a model of the ocean's mean dynamic topography, and 1000 historical astrogeodetic vertical deflections. Updates to these data will be posted on the Intergovernmental Committee on Surveying and Mapping GitHub repository (https://github.com/icsm-au), together with a readme.txt file describing them.

\section{KEYWORDS}

GPS-levelling, vertical deflections, gravity model testing, Australia, vertical datum offsets, heights

\section{Introduction and motivation}

When carrier-phase-based relative GPS (Global Positioning System) became a geodetic surveying tool (e.g. Bock, Abbot, Counselman, Gourevitch, \& King, 1985; Counselman \& Gourevitch, 1981), gravimetric geoid computation encountered a revival (e.g. Engelis, Rapp, \& Tscherning, 1984; Engelis, Rapp, \& Bock, 1985; Kearsley, 1986; Denker \& Wenzel, 1987). This was because of its practical utility in transforming ellipsoidal height differences from relative GPS surveys to orthometric height differences (e.g. Kearsley, 1988a). GPS and a geoid model were, and still are, an attractive alternative to differential levelling over long distances on the grounds of efficiency and cost, but provided that the gravimetric geoid model is sufficiently precise and accurate.

Co-located GPS and levelling data were also used to provide a test of gravimetric geoid models (e.g. Kearsley, 1988b), and continue to be used today (e.g. http://icgem.gfzpotsdam.de/ICGEM/). There is a subtle distinction between the geoid and the quasigeoid on land, where GPS and the geoid are used to determine orthometric heights, and GPS and the quasigeoid are used to determine normal heights (e.g. Featherstone \& Kuhn, 2006). GPS-levelling tests of quasi/geoid models can be applied in a relative sense over GPS baselines or in an absolute sense when the GPS ellipsoidal height has been determined at a single point (e.g. Featherstone, 2001). Another test of quasi/geoid models comes from astrogeodetic vertical deflections (e.g. Jekeli, 1999; Hirt, Marti, Bürki, \& Featherstone, 2010; Hirt, Gruber, \& Featherstone, 2011).

The use of GPS-levelling simply to test gravimetric quasi/geoid models has evolved to the use of GPS and the quasi/geoid to question the veracity of local vertical datums (e.g. Featherstone \& Filmer, 2008, 2012; Penna, Featherstone, Gazeaux, \& Bingham, 2013). GPS levelling is sometimes used to fit surfaces to account for the separation between the gravimetric model and local vertical datum (e.g. Milbert, 1995; Featherstone, 1998; Smith \& Roman, 2001; Brown, Feather- stone, Hu, \& Johnston, 2011). This short note is motivated by Milbert (1998) so as to document not only the GPS-levelling but also the vertical deflection data available in Australia and release them into the public domain.

\section{GPS-levelling data}

GPS-levelling has been used for decades in Australia to test global and regional quasi/geoid models (e.g. Amos \& Featherstone, 2003; Claessens, Featherstone, Anjasmara, \& Filmer, 2009; Featherstone \& Guo, 2001; Featherstone et al., 2001, 2011, 2017; Kearsley \& Govind, 1991; Kearsley \& Holloway, 1989; Pearse, Kearsley, \& Morgan, 1995; Steed \& Hotznagel, 1994; Zhang \& Featherstone, 1995). A rather outdated (circa year 2000) set of 201 Australian GPS-levelling data is still being used by the ICGEM (http://icgem.gfz-potsdam.de/ICGEM/) to evaluate global Earth gravitational models (EGMs), thus motivating our description and public release of these newer data. As of August 2017, there is a total of 7635 GPS-levelling data points (Figure 1).

The raw GPS observations were provided to Geoscience Australia (the national geodetic agency) by Australian State and Territory geodetic agencies. These are static dualfrequency occupations of at least six hours' duration at benchmarks of the Australian Height Datum (AHD). The ellipsoidal heights were computed by Geoscience Australia using Bernese version 5.2 (Dach, Lutz, Walser, \& Fridez, 2015) on the Geocentric Datum of Australia 2020 (GDA2020; GRS80 ellipsoid), which is a regional realisation of ITRF2014 (Altamimi, Rebischung, Métivier, \& Xavier, 2016), projected to epoch 2020.0 using Australian station velocities. The GDA2020 ellipsoidal heights were output from a least-squares adjustment (LSA) along with the associated positional uncertainty (at one sigma). 


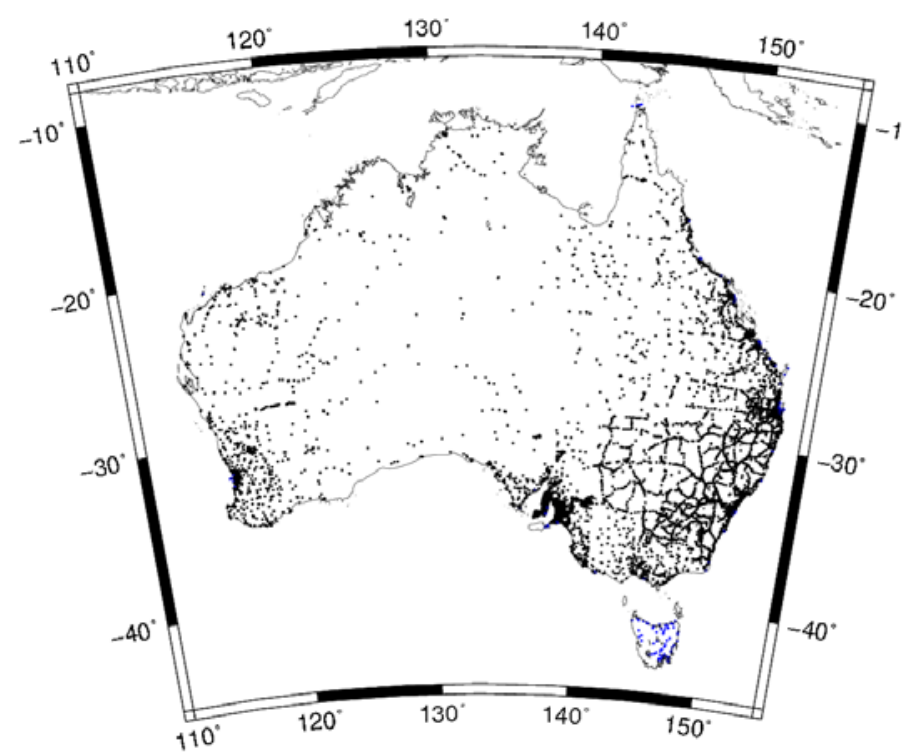

Figure 1: Spatial coverage of the August 2017 Australian GPS-levelling data. Black dots are points on the Australian mainland (a single vertical datum). Blue dots are the separate vertical datums on Tasmania and coastal islands near the mainland. GPS-levelling points on Lord

Howe Island, Cocos/Keeling Islands and Christmas Island are not shown, but are provided with the Electronic Supplementary Material.

The utility of GPS-levelling for testing quasi/geoid models can be restricted by distortions in the vertical datum to which the levelling is referred. These distortions are caused by (1) constraining the vertical datum to mean sea level at tide gauges, which is separated from the geoid by the ocean's time-mean dynamic topography (MDT) (e.g. Bowie, 1929) and other oceanographic effects, and (2) errors in the levelling observations.

The levelling data provided for Australia therefore come from two LSAs. Source 1 is the 'official' published AHD heights of the benchmarks from the 1971 LSA (Roelse, Granger, \& Graham, 1971), together with an estimate of their uncertainty (at one sigma), which has not previously been publicly available. Source 2 is a LSA of the Australian National Levelling Network (ANLN) that is constrained at 32 tide gauges to mean sea level values that are corrected for the MDT using the Australian Commonwealth Scientific and Industrial Research Organisation Atlas of Regional Seas 2009 (CARS2009; Dunn \& Ridgway, 2002; Ridgway, Dunn, \& Wilkin, 2002). The use of MDT values from CARS2009 at the tide gauges results in the adjusted levelling network being more closely aligned to the geoid (Featherstone et al., 2017; Filmer, Featherstone, \& Claessens, 2014). The rationale for the latter LSA is that there are remaining distortions in the AHD that cannot be removed by a tilted plane alone (Featherstone \& Filmer, 2012) owing to uncorrected gross, random and systemic levelling errors (e.g. Morgan, 1992; Roelse et al., 1971; Filmer \& Featherstone, 2009, 2011). In addition, the AHD uses normal-orthometric heights through the use of the Rapp (1961) normalorthometric correction using normal gravity from the Geodetic Reference System 1967 (GRS67; International Association of Geodesy, 1971). The CARS2009-constrained LSA of the ANLN provides normal heights, using gravity values from EGM2008 through the application of the normal correction and GRS80 normal gravity (Moritz, 1980), as described in Filmer, Featherstone and Kuhn (2010).

The GPS-levelling data include some of Australia's offshore territories, which are technically on separate vertical datums, as is the AHD on Tasmania (Featherstone, 2000; Filmer \& Featherstone, 2012; Rizos, Coleman, \& Ananga, 1991). Although they are all termed AHD heights, they refer to mean sea level observed at a tide gauge(s) on each island. These comprise: Lord Howe Island (1 point), Cocos/Keeling Islands (14 points), Christmas Island (20 points), Tasmania (76 points) and coastal islands close to the Australian mainland (138 points). We identified the coastal islands using the fullresolution shoreline in the Generic Mapping Tools (GMT; Wessel, Smith, Scharroo, Luis, \& Wobbe, 2013) software (http://www.soest.hawaii.edu/wessel/gshhg/), which is an update of Wessel and Smith (1996). However, even the highest resolution shoreline option in GMT was not always able to discriminate between peninsulas and islands, so visual inspection of satellite and aerial imagery via Google Earth was used for confirmation.

Using these GPS-levelling data, we estimated the offset to these vertical datums (excepting Tasmania) by taking the mean of the GPS-levelling minus the EGM2008 global quasigeoid model (Pavlis, Holmes, Kenyon, \& Factor, 2012, 2013) as a proxy for the offsets between the remote island vertical datums and the AHD mainland. However, this is problematic owing to the north-south tilt in the AHD, which causes the vertical datum offsets to be a function of latitude (Featherstone, 2000). Therefore, we removed the north-south tilt in the AHD of $22.2 \mathrm{~mm} /$ degree from Featherstone and Filmer (2012) before calculating the vertical datum offsets (Table 1). The small sample sizes on the islands prevent a more robust estimate of the vertical datum offsets, but this may be refined as more data become available. The standard deviations in Table 1 are determined from linear propagation of the standard deviations of fit to each vertical datum, assuming independence.

The GPS-levelling data are provided as Electronic Supplementary Material to this article in a Microsoft Excel file named 'AustralianGPSlevellingAug2017.xlsx'. This contains two tabs, one called AHD with the 'official' AHD normal-orthometric heights, and another called CARS2009 with the readjusted normal heights. The AHD tab comprises eight columns of an (A) ID number, (B) GDA2020 longitude in decimal degrees, (C) GDA2020 latitude in decimal degrees, (D) GDA2020 ellipsoidal height $(h)$ in metres, (E) standard deviation of the GDA2020 ellipsoidal height in metres (scaled up by a factor of 10 from the optimistic output of the GDA2020 LSA; cf. Rothacher, 2002, (F) AHD normal-orthometric height $(H)$ in metres, (G) standard deviation of the AHD height in metres, and (E) geometrically computed quasigeoid height relative to the GRS80 reference ellipsoid $(\zeta=h-H)$. The CARS2009 tab is the same but replaces the AHD heights by the readjusted normal heights (column F) and recomputes the geometric quasigeoid height (column E). The island stations are located at the bottom of each tab.

\begin{tabular}{|l|r|r|r|}
\hline Island vertical datum & Points & $\begin{array}{l}\text { Offset from } \\
\text { AHD }(\mathrm{m})\end{array}$ & STD (m) \\
\hline Christmas Island & 20 & -0.261 & \pm 0.122 \\
\hline Cocos/Keeling Islands & 14 & -0.404 & \pm 0.140 \\
\hline Lord Howe Island & 1 & +0.709 & N/A \\
\hline
\end{tabular}

Table 1: Estimated offsets $(\mathrm{m})$ between Australian island vertical datums and the AHD (mainland) 


\section{Vertical deflection data}

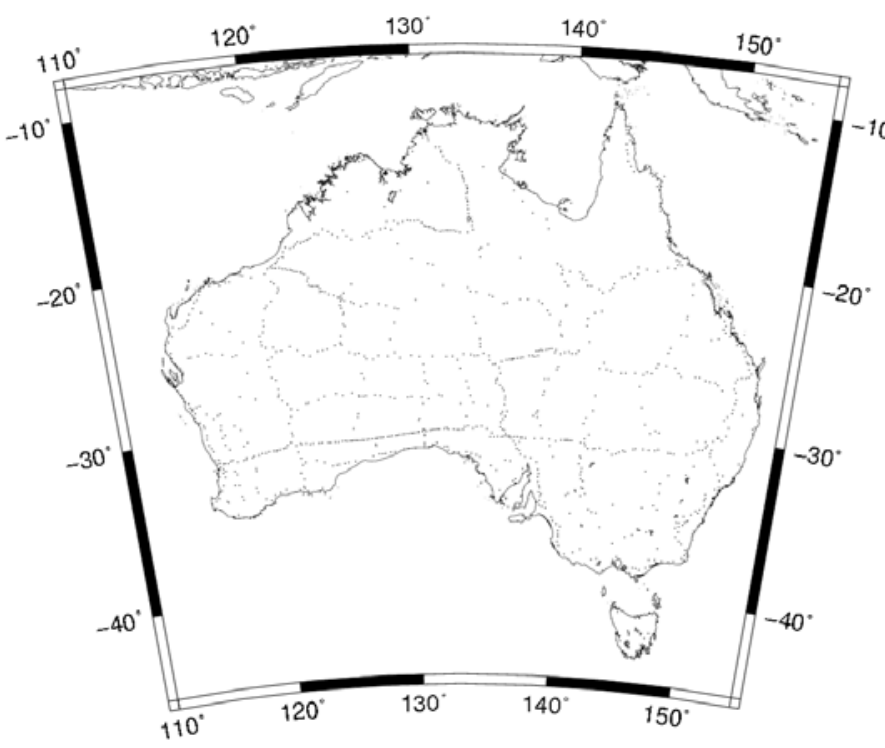

Figure 2: Spatial coverage of the August 2017 Australian vertical deflection data.

Vertical deflections/deviations (the angular difference between the ellipsoidal normal and gravity vector) provide a more powerful test of the high-frequency gravity field than GPS-levelling because they are a higher-order derivative of the disturbing potential (e.g. Hirt et al., 2010, 2011; Jekeli, 1999). They comprise a north-south component $(\xi)$ and an east-west component $(\eta)$ and are typically a few to tens of arc-seconds in magnitude. There are also some subtleties with the definition of the vertical deflection because of the curvature and torsion of the plumbline, notably Helmert on the Earth's surface vs Pizzetti at the geoid (e.g. Jekeli, 1999), and absolute/geocentric vs relative (e.g. Featherstone \& Rüeger, 2000).

A historical (typically 1960s and 1970s) set of 1080 Australian vertical deflections was discovered by the first author in an archive at Oxford University (Figure 2). This had been sent in hardcopy format to Brigadier Guy Bomford, reader in geodesy at Oxford, by his son Anthony Bomford, a former director of the then National Mapping Agency (thereafter AUSLIG and now Geoscience Australia). These astrogeodetic vertical deflections used timed star observations of astrogeodetic latitude and longitude over several nights per station (e.g. Bomford, Cook, \& McCoy, 1970) and follow the Helmert definition as they are at the Earth's surface (e.g. Jekeli, 1999). Subsets of these historical deflections have been used to (1) determine parameters for the Australian National Spheroid (ANS; Lambert, 1962), (2) for the establishment of the (regional, not geocentric) Australian Geodetic Datum 1966 (AGD66; Bomford, 1964, 1967), (3) compute geoid maps with respect to the local ANS (Fisher \& Slutsky, 1967; Fryer, 1970, 1972), and (4) relate the AGD66 and ANS to the Earth's centre of mass (Mather, 1970; Mather \& Fryer, 1970a, 1970b).

These relative vertical deflections have since been converted to absolute values (i.e., with respect to the geocentric GRS80 ellipsoid) and used for gravity field model testing in a variety of guises over Australia: the global EGM2008 (Pavlis et al., 2012, table 9) and regional quasigeoid models (Featherstone, 2006; Featherstone \& Morgan, 2007; Featherstone et al., 2017), assessment of satellite-derived geoid models (Hirt et al., 2011), and even in an attempt to fit a regional quasigeoid model to them (Featherstone \& Lichti, 2009). However, the historical nature of vertical deflections makes them prone to larger uncertainty (cf. Featherstone \& Olliver, 2013).

No per-station formal error estimates are known for these historical Australian vertical deflections. Instead, some general error estimates have been made for subsets of the whole database. Bomford et al. (1970, p. 2) give estimates of \pm 0.38 " for $\xi$ and \pm 0.76 " for $\eta$ from 510 observations made between 1967 and 1969. Fryer (1970, table 3.1, p. 51) gives estimates for different instruments that range from \pm 0.22 " to \pm 0.60 " for $\xi$ and from $\pm 0.40^{\prime \prime}$ to \pm 1.00 " for $\eta$. Kearsley $(1976$, p. 135) uses the values of \pm 0.25 " for $\xi$ and $\pm 0.45^{\prime \prime}$ for $\eta$ taken from Fryer (1970), and provides a more detailed error analysis for four stations in areas of rugged terrain.

These 1080 astrogeodetic vertical deflection data are provided as Electronic Supplementary Material to this article in a Microsoft Excel file named 'AustralianVerticalDeflectionsAug2017.xlsx'. These have been recalculated for the horizontal geodetic coordinates on GDA2020 (i.e., absolute Helmert deflections). The file contains a single tab comprising nine columns. Column $A$ is the station name, and columns $B$ and $C$ are the astrogeodetic/natural latitude $(\Phi)$ and longitude $(\Lambda)$, respectively from the original star observations. Column $D$ gives the AHD heights in metres, but these should not be used with column $\mathrm{G}$ to calculate $(\zeta=h-H)$ as several points in column D have not been levelled, instead coming from less precise trigonometrical heighting. Columns $E, F$ and $G$ respectively give the GDA2020 latitude $(\varphi)$, longitude $(\lambda)$ (decimal degrees) and ellipsoidal height (metres) from the national LSA. Column $\mathrm{H}$ is the calculated north-south deflection component $(\xi=\Phi$ $\varphi)$ and column I is the calculated east-west component $[\eta=$ $(\Lambda-\lambda) \tan \varphi]$; both are in arc-seconds.

\begin{tabular}{|l|r|r|r|r|r|r|}
\hline & \multicolumn{2}{|c|}{ EGM2008 } & \multicolumn{2}{c|}{ AGQG2009 } & \multicolumn{2}{c|}{ AGQG2017 } \\
\hline & NS $(\xi)$ & EW $(\eta)$ & NS $(\xi)$ & EW $(\eta)$ & NS $(\xi)$ & EW $(\eta)$ \\
\hline Max & 2.94 & 2.94 & 2.38 & 2.97 & 2.43 & 2.89 \\
\hline Min & -2.87 & -2.91 & -2.86 & -2.85 & -2.80 & -2.78 \\
\hline mean & -0.22 & -0.10 & -0.22 & -0.10 & -0.21 & -0.08 \\
\hline STD & \pm 0.71 & \pm 0.94 & \pm 0.60 & \pm 0.88 & \pm 0.58 & \pm 0.85 \\
\hline Outliers & 16 & 27 & 13 & 23 & 12 & 25 \\
\hline
\end{tabular}

Table 2: Differences (arc-seconds) between 1,080 Australian astrogeodetic deflections and model-based vertical deflections after rejection of points that exceed a threshold of 3 arc-seconds in magnitude.

We compared the GDA2020-based absolute Helmert astrogeodetic deflections with deflections calculated from EGM2008 (Pavlis et al., 2012, 2013), AGQG2009 (Featherstone et al., 2011) and AGQG2017 (Featherstone et al., 2017) (Table 2). Deflections were synthesised from EGM2008 at the GDA2020 ellipsoidal height of each astrogeodetic station (column G) using the isGrafLab software (Bucha \& Janák, 2014). Deflections were calculated from the longitudinal and latitudinal horizontal gradients of the AGQG2009 and AGQG2017 gravimetric quasigeoid models (e.g. Featherstone \& Rüeger, 2000). Even though the Australian astrogeodetic deflections are historical data, there are surprisingly few outliers. We have retained these in the data release, but they have been removed by a 3 arc-second rejection threshold for the results in Table 2 (cf. Pavlis et al., 2012). The larger standard deviations for the east-west vertical deflections $(\eta)$ most likely reflect timing errors in these historical observations, though they could also be due to errors in the star catalogues used. This is also reflected in the estimated precision of subsets of 
the astronomical observations (Bomford et al., 1970; Fryer, 1970; Kearsley, 1976).

\section{Summary and concluding remarks}

This short note has described GPS-levelling and vertical deflection ground-truth data for testing gravity field models in Australia (release August 2017), which are provided as Electronic Supplementary Materials. Updates to the GPS-levelling and vertical deflection data will be posted on the Intergovernmental Committee on Surveying and Mapping GitHub repository (https://github.com/icsm-au) together with a readme.txt file describing them. We have used the GPS-levelling data to estimate offsets between some local vertical datums and used the vertical deflections to assess one global and two regional quasigeoid models.

These data can not only be freely used to assess global gravity field models on a continental scale (cf. http://icgem.gfz-potsdam.de/ICGEM/), but also be used to assess Australian quasigeoid models computed by other groups using their own techniques and software (cf. Duquenne, 2007; Ismail \& Jamet, 2015; Valty, Duquenne, \& Panet, 2009; Yildiz, Forsberg, Ågren, Tscherning, \& Sjöberg,2011). This is possible because Australian land gravity and terrain data are freely available via Geoscience Australia's GADDS system (http://www.geoscience.gov.au/cgibin/mapserv?map=/nas/web/ops/prod/apps/mapserver/gadd s/wms_map/gadds.map\&mode=browse). We would be pleased to collaborate and cooperate with any such interested parties.

\section{Acknowledgements}

Part of this work has been supported financially by the Cooperative Research Centre for Spatial Information, whose activities are funded by the Business Cooperative Research Centres Programme, and by Geoscience Australia. Figures were produced with GMT in Lambert projection (Wessel et al., 2013). Nicholas Brown and Jack McCubbine publish this paper with the permission of the CEO, Geoscience Australia. Finally, thanks go to the editor and two anonymous reviewers.

\section{Disclosure statement}

No potential conflict of interest was reported by the authors.

\section{Funding}

This work was supported by the CRC for Spatial Information [grant number P1.24].

\section{ORCID}

W.E. Featherstone http://orcid.org/0000-0001-9644-4535

J.C. McCubbine http://orcid.org/0000-0002-6939-1340

M.S. Filmer http://orcid.org/0000-0002-3555-4869

\section{References}

Altamimi, Z., Rebischung, P., Métivier, L., \& Xavier, C. (2016). ITRF2014: A new release of the International Terrestrial Reference Frame modeling nonlinear station motions. Journal of Geophysical Research - Solid Earth, 121 (8), 6109-6131. doi: 10.1002/2016JB013098.

Amos, M. J., \& Featherstone, W. E. (2003). Comparisons of global geopotential models with terrestrial gravity field data over New Zealand and Australia. Geomatics Research Australasia, 78, 67-84.

Bock, Y., Abbot, R. I., Counselman III, C. C., Gourevitch, S. A., \& King, R. W. (1985). Establishment of three-dimensional geodetic control by interferometry with the Global Positioning System. Journal of Geophysical Research Solid Earth, 90 (B9), 7689-7703. doi: 10.1029/JB090iB09p07689.

Bomford, A. G. (1964). The geodetic adjustment of Australia. The Australian Surveyor, 20 (2), 97-106. doi: 10.1080/00050326.1964.10439835.

Bomford, A. G. (1967). The geodetic adjustment of Australia 1963-1966.

Survey Review, 19 (144), 52-71. doi: 10.1179/sre.1967.19.144.52.
Bomford, A. G., Cook, D. P., \& McCoy, F. J. (1970). Astronomic observations in the Division of National Mapping 1966-1970, Technical Report 10. Canberra, ACT: Division of National Mapping, Australia.

https://www.xnatmap.org/report_tdnm/tr10\%202/tr10\%202.html

Bowie, W. (1929). Tilting of mean sea level. Gerlands Beitraege zur Geophysik, 23, 97-98.

Brown, N. J., Featherstone, W. E., Hu, G., \& Johnston, G. M. (2011). AUSGeoid09: a more direct and more accurate model for converting ellipsoidal heights to AHD heights. Journal of Spatial Science, 56 (1), 27-37. doi: 10.1080/14498596.2011.580498.

Bucha, B., \& Janák, J. (2014). A MATLAB-based graphical user interface program for computing functionals of the geopotential up to ultra-high degrees and orders: Efficient computation at irregular surfaces. Computers \& Geosciences, 66, 219-227. doi: 10.1016/j.cageo.2014.02.005.

Claessens, S. J., Featherstone, W. E., Anjasmara, I. M., \& Filmer, M. S. (2009). Is Australian data really validating EGM2008, or is EGM2008 just in/validating Australian data? Newton's Bulletin, 4, 207-251.

Counselman, C. C., \& Gourevitch, S. A. (1981). Miniature interferometer terminals for Earth surveying: Ambiguity and multipath with Global Positioning System. IEEE Transactions on Geoscience and Remote Sensing, 19 (4), 244252. doi: 10.1109/TGRS.1981.350379.

Dach, R., Lutz, S., Walser, P., \& Fridez, P. (Eds) (2015). Bernese GNSS Software Version 5.2. User manual. Bern Switzerland: Astronomical Institute, University of Bern, Open Publishing. doi: 10.7892/boris.72297.

Denker, H., \& Wenzel, H. G. (1987). Local geoid determination and comparison with GPS results. Bulletin Géodésique, 61 (4), 349-366. doi: 10.1007/BF02520560.

Dunn, J. R., \& Ridgway, K. R. (2002). Mapping ocean properties in regions of complex topography. Deep Sea Research, 49 (3), 591-604. doi: 10.1016/S0967-0637(01)00069-3.

Duquenne, H. (2007). A data set to test geoid computation methods. Harita Dergisi, 18, 61-65.

Engelis, T., Rapp, R. H., \& Bock, Y. (1985). Measuring orthometric height differences with GPS and gravity data. Manuscripta Geodaetica, 10 (3), 187194.

Engelis, T., Rapp, R. H., \& Tscherning, C. C. (1984). The precise computation of precise geoid undulation differences with comparison to results obtained from the Global Positioning System. Geophysical Research Letters, 11 (9), 821-824. doi: 10.1029/GL011i009p00821.

Featherstone, W. E. (1998). Do we need a gravimetric geoid or a model of the base of the Australian Height Datum to transform GPS heights? The Australian Surveyor, 43 (4), 273-280.

Featherstone, W. E. (2000). Towards the unification of the Australian Height Datum between the mainland and Tasmania using GPS and AUSGeoid98. Geomatics Research Australasia, 73, 33-54.

Featherstone, W. E. (2001). Absolute and relative testing of gravimetric geoid models using Global Positioning System and orthometric height data. Computers \& Geosciences, 27 (7), 807-814. doi: 10.1016/S0098-3004(00)001692.

Featherstone, W. E. (2006). Yet more evidence for a north-south slope in the Australian Height Datum. Journal of Spatial Science, 51 (2), 1-6. doi: 10.1080/14498596.2006.9635076.

Featherstone, W. E., \& Filmer, M. S. (2008). A new GPS-based evaluation of distortions in the Australian Height Datum in Western Australia. Journal of the Royal Society of Western Australia, 91 (2), 199-206.

Featherstone W. E., \& Filmer, M. S. (2012). The north-south tilt in the Australian Height Datum is explained by the ocean's mean dynamic topography. Journal of Geophysical Research - Oceans, 117 (C8), C08035. doi: 10.1029/2012JC007974.

Featherstone, W. E., \& Guo, W. (2001). Evaluations of the precision of AUSGeoid98 versus AUSGeoid93 using GPS and Australian Height Datum data. Geomatics Research Australasia, 74, 75-102.

Featherstone, W. E., \& Kuhn, M. (2006). Height systems and vertical datums: a review in the Australian context. Journal of Spatial Science, 51 (1), 21-42. doi: 10.1080/14498596.2006.9635062.

Featherstone, W. E., \& Lichti, D. D. (2009). Fitting gravimetric geoid models to vertical deflections, Journal of Geodesy, 83 (6), 583-589. doi: 10.1007/s00190-008-0263-4.

Featherstone, W. E., \& Morgan, L. (2007). Validation of the AUSGeoid98 model in Western Australia using historic astrogeodetically observed deviations of the vertical. Journal of the Royal Society of Western Australia, 90 (3), 143-149.

Featherstone, W. E., \& Olliver, J. G. (2013). Assessment of EGM2008 over Britain using vertical deflections, and problems with historical data. Survey Review, 45 (332), 319-324. doi: 10.1179/1752270613Y.0000000048.

Featherstone, W. E., \& Rüeger, J. M. (2000). The importance of using deviations of the vertical in the reduction of terrestrial survey data to a geocentric 
datum. The Trans-Tasman Surveyor, 1 (3), 46-61. [Erratum in The Australian Surveyor, 47 (1), 7]

Featherstone, W. E., Kirby, J. F., Hirt, C., Filmer, M. S., Claessens, S. J., Brown, N. J., Hu, G., \& Johnston, G. M. (2011). The AUSGeoid09 model of the Australian Height Datum. Journal of Geodesy, 85 (3), 133-150. doi: 10.1007/s00190-010-0422-2.

Featherstone, W. E., Kirby, J. F., Kearsley, A. H. W., Gilliland, J. R., Johnston, G. M., Steed, J., Forsberg, R., \& Sideris, M. G. (2001). The AUSGeoid98 geoid model of Australia: data treatment, computations and comparisons with GPS-levelling data. Journal of Geodesy, 75 (5-6), 313-330. doi: 10.1007/s001900100177.

Featherstone, W. E., McCubbine, J. C., Brown, N. J., Claessens, S. J., Filmer, M. S., \& Kirby, J. F. (2017). The first Australian gravimetric quasigeoid model with location-specific uncertainty estimates. Journal of Geodesy, doi: 10.1007/s00190-017-1053-7.

Filmer, M. S., \& Featherstone, W. E. (2009). Detecting spirit-levelling errors in the AHD: recent findings and some issues for any new Australian height datum. Australian Journal of Earth Sciences, 56 (4), 559-569. doi: 10.1080/08120090902806305.

Filmer, M. S., \& Featherstone, W. E. (2011). Error propagation for three common height-system corrections to differential levelling. Journal of Spatial Science, 56 (1), 39-58. doi: 10.1080/14498596.2011.567410.

Filmer, M. S., \& Featherstone, W. E. (2012). A re-evaluation of the offset in the Australian Height Datum between mainland Australia and Tasmania. Marine Geodesy, 35 (1), 107-119. doi: 10.1080/01490419.2011.634961.

Filmer, M. S., Featherstone, W. E., \& Claessens, S. J. (2014). Variance component estimation uncertainty for unbalanced data: application to a continentwide vertical datum. Journal of Geodesy, 88 (11), 1081-1093. doi: 10.1007/s00190-014-0744-6.

Filmer, M. S., Featherstone, W. E., \& Kuhn, M. (2010). The effect of EGM2008based normal, normal-orthometric and Helmert orthometric height systems on the Australian levelling network. Journal of Geodesy, 84 (8), 501-513. doi:10.1007/s00190-010-0388-0.

Fischer, I., \& Slutsky, M. (1967). A preliminary geoid chart of Australia. The Australian Surveyor, 21 (8), 327-332. doi: 10.1080/00050326.1967.10440069.

Fryer, J. G. (1970). The effect of the geoid on the Australian geodetic network. UNISURV Report 20, School of Surveying, University of New South Wales, Kensington, Australia.

Fryer, J. G. (1972). The Australian geoid. The Australian Surveyor, 24 (4), 203214. doi: 10.1080/00050326.1972.10440630.

Hirt, C., Gruber, T., \& Featherstone, W. E. (2011). Evaluation of the first GOCE static gravity field models using terrestrial gravity, vertical deflections and EGM2008 quasigeoid heights. Journal of Geodesy, 85 (10), 723-740. doi: 10.1007/s00190-011-0482-y.

Hirt, C., Marti, U., Bürki, B., \& Featherstone, W. E. (2010). Assessment of EGM2008 in Europe using accurate astrogeodetic vertical deflections and omission error estimates from SRTM/DTM2006.0 residual terrain model data. Journal of Geophysical Research - Solid Earth, 115, B10404. doi: 10.1029/2009JB007057

International Association of Geodesy (1971). Geodetic Reference System 1967. Paris France: Bulletin Géodésique, Special Publication No. 3.

Ismail, Z., \& Jamet, O. (2015). Accuracy of unmodified Stokes' integration in the R-C-R procedure for geoid computation. Journal of Applied Geodesy, 9 (2), 112-122. doi: 10.1515/jag-2014-0026.

Jekeli, C. (1999). An analysis of vertical deflections derived from high-degree spherical harmonic models. Journal of Geodesy, 73 (1), 10-22. doi: 10.1007/s001900050213.

Kearsley, A. H. W. (1976). The computation of deflections of the vertical from gravity anomalies, UNISURV Report S15. Kensington, NSW: School of Surveying, University of New South Wales.

Kearsley, A. H. W. (1986). Data requirements for determining precise relative geoid heights from gravimetry. Journal of Geophysical Research - Solid Earth, 91 (B9), 9193-9201. doi: 10.1029/JB091iB09p09193.

Kearsley, A. H. W. (1988a). The determination of the geoid-ellipsoid separation for GPS levelling. The Australian Surveyor, 34 (1), 11-18. doi 10.1080/00050326.1988.10438999.

Kearsley, A. H. W. (1988b). Tests on the recovery of precise geoid height differences from gravimetry. Journal of Geophysical Research - Solid Earth, 93 (B6), 6559-6570. doi: 10.1029/JB093iB06p06559.

Kearsley, A. H. W., \& Govind, R. (1991). Geoid evaluation in Australia - a status report. The Australian Surveyor, 36 (1), 30-40. doi: 10.1080/00050326.1991.10438710

Kearsley, A. H. W., \& Holloway, R. D. (1989). Tests on geopotential models in the Australian region. Australian Journal of Geodesy Photogrammetry and Surveying, 50, 1-17.
Lambert, B. P. (1962). A figure of the Earth for Australia. The Australian Surveyor, 19 (3), 178-185. doi: 10.1080/00050326.1962.10439706.

Mather, R. S. (1970). The geocentric orientation vector for the Australian Geodetic Datum. Geophysical Journal of the Royal Astronomical Society, 22 (1), 55-81. doi: 10.1111/j.1365-246X.1971.tb03583.x.

Mather, R. S., \& Fryer, J. G. (1970a). Geoidal studies in Australia. Survey Review, 20 (150), 268-282. doi: 10.1179/sre.1970.20.156.268.

Mather, R. S., \& Fryer, J. G. (1970b). Orientation of the Australian Geodetic Datum. The Australian Surveyor, 23 (1), 5-14. doi: 10.1080/00050326.1970.10440195.

Milbert, D. G. (1995). Improvement of a high resolution geoid height model in the U.S. by GPS height on NAVD88 benchmarks. IGeS Bulletin, 4, 13-36.

Milbert, D. G. (1998). Documentation for the GPS benchmark data set of 23July-98. IGeS Bulletin, 8, 29-42.

Morgan, P. J. (1992). An analysis of the Australian Height Datum: 1971. The Australian Surveyor, 37 (1), 46-63. doi: 10.1080/00050326.1992.10438774. Moritz, H. (1980). Geodetic reference system 1980. Bulletin Géodésique 54(3): 395-405. doi: 10.1007/BF02521480.

Pavlis, N. K., Holmes, S. A., Kenyon, S. C., \& Factor, J. K. (2012). The development and evaluation of the Earth Gravitational Model 2008 (EGM2008). Journal of Geophysical Research - Solid Earth, 117 (B4), B04406. doi: 10.1029/2011JB008916.

Pavlis, N. K., Holmes, S. A., Kenyon, S. C., \& Factor, J. K. (2013). Correction to "The development and evaluation of the Earth Gravitational Model 2008 (EGM2008)". Journal of Geophysical Research - Solid Earth, 118 (B5), 2633. doi: 10.1029/jgrb.50167.

Pearse, M. B., Kearsley, A. H. W., \& Morgan, P. (1995). Height comparisons on the Australian National GPS Network (ANN): First results. In H. Sünkel \& I. Marson (Eds.). Gravity and Geoid. International Association of Geodesy Symposia, vol 113 (pp. 439-445). Berlin, Heidelberg: Springer doi:

10.1007/978-3-642-79721-7_45.

Penna, N. T., Featherstone, W. E., Gazeaux, J., \& Bingham, R. J. (2013). The apparent British sea slope is caused by systematic errors in the levellingbased vertical datum. Geophysical Journal International, 194 (2), 772-786. doi: $10.1093 /$ gji/ggt161

Rapp, R. H. (1961). The orthometric height. MSc dissertation, Department of Geodetic Science, Ohio State University.

Ridgway, K. R., Dunn, J. R., \& Wilkin, J. L. (2002). Ocean interpolation by four dimensional weighted least squares-application to the waters around Australasia. Journal of Atmospheric and Oceanic Technology, 19 (9), 1357-1375. doi: 10.1175/1520-0426(2002)019<1357:OIBFDW>2.0.CO;2.

Rizos, C., Coleman, R., \& Ananga, N. (1991). The Bass Strait GPS survey: Preliminary results of an experiment to connect Australian height datums. Australian Journal of Geodesy, Photogrammetry and Surveying, 55, 1-25.

Roelse, A., Granger, H. W., \& Graham, J. W. (1971). The adjustment of the Australian levelling survey 1970-1971. Technical Report 12. Canberra ACT: Division of National Mapping.

Rothacher, M. (2002). Estimation of station heights with GPS. In H. Drewes, A. H. Dodson, L. P. S. Fortes, L. Sánchez \& P. Sandoval (Eds.). Vertical Reference Systems. International Association of Geodesy Symposia, vol 124 (pp. 8190). Berlin, Heidelberg: Springer. doi: 10.1007/978-3-662-04683-8 17.

Smith D. A., \& Roman, D. R. (2001). GEOID99 and G99SSS: 1-arc-minute geoid models for the United States. Journal of Geodesy, 75 (9-10), 469-490. doi: 10.1007/s001900100200.

Steed, J., \& Hotznagel, S. (1994). AHD heights from GPS using AUSGEOID93. The Australian Surveyor, 39 (1), 21-27. doi 10.1080/00050326.1994.10441581

Valty, P., Duquenne, H., \& Panet, I. (2009). Auvergne dataset: Testing severa geoid computation methods. In S. Kenyon, M. Pacino \& U. Marti (Eds.). Geodesy for Planet Earth. International Association of Geodesy Symposia, vol 136 (pp. 465-472). Berlin, Heidelberg: Springer. doi: 10.1007/978-3-64220338-1.

Wessel, P., \& Smith, W. H. F. (1996). A global, self-consistent, hierarchical, high-resolution shoreline database. Journal of Geophysical Research - Solid Earth, 101 (B4), 8741-8743. doi: 10.1029/96JB00104

Wessel, P., Smith, W. H. F., Scharroo, R., Luis, J. F., \& Wobbe, F. (2013). Generic Mapping Tools: Improved version released, EOS - Transactions of the AGU, 94 (45), 409-410. doi: 10.1002/2013EO450001.

Yildiz, H., Forsberg, R., Ågren, J., Tscherning, C. C., \& Sjöberg, L. E. (2011) Comparison of remove-compute-restore and least squares modification of Stokes' formula techniques to quasigeoid determination over the Auvergne test area. Journal of Geodetic Science, 2 (1), 53-64. doi: 10.2478/v10156011-0024-9.

Zhang, K. F., \& Featherstone, W. E. (1995). The statistical fit of recent geopotential models to the gravity field of Australia. Geomatics Research Australasia, 63, 1-18. 